\title{
Hsp90 inhibitor induces KG-1a cell differentiation and apoptosis via Akt/NF-кB signaling
}

\author{
JIN-HONG QIN ${ }^{1,2}$, KUN WANG $^{1}$, XIN-LU FU ${ }^{3}$, PENG-JUN ZHOU ${ }^{1}$, ZHONG LIU $^{1,2}$, DAN-DAN XU ${ }^{1}$, \\ YI-FEI WANG ${ }^{1,2}$, DE-PO YANG ${ }^{4}$, QIU-LING XIE ${ }^{1,2}$ and QIU-YING LIU ${ }^{1,2,4}$ \\ ${ }^{1}$ Guangzhou Jinan Biomedicine Research and Development Center, National Engineering Research Center \\ of Genetic Medicine, and ${ }^{2}$ Guangdong Provincial Key Laboratory of Bioengineering Medicine, \\ Jinan University, Guangzhou, Guangdong 510632; ${ }^{3}$ Laboratory Animal Center and ${ }^{4}$ School of Pharmaceutical Sciences, \\ Sun Yat-Sen University, Guangzhou, Guangdong 510275, P.R. China
}

Received December 3, 2016; Accepted May 23, 2017

DOI: $10.3892 /$ or.2017.5797

\begin{abstract}
Heat-shock protein 90 (Hsp 90) acts as a molecular chaperone that maintains protein stability and regulates cell proliferation, survival, differentiation and apoptosis. The present study investigated the effect of Hsp90 inhibition on human acute myeloid leukemia (AML) cells using the novel small-molecule inhibitor SNX-2112. We found that SNX-2112 more potently inhibited KG-1a cell growth than the classical Hsp90 inhibitor 17-(2-dimethylaminoethyl)amino-17-demethoxygeldanamycin as determined by CCK-8 assay. Flow cytometry was used to examine the cell cycle, differentiation, and apoptosis, and western blotting and qRT-PCR were used to analyze the underlying mechanism. The results revealed that low concentrations of SNX-2112 arrested the cells in the G2/M phase and induced their differentiation and apoptosis, possibly by suppressing Akt and inhibitor of $\kappa \mathrm{B}$ kinase, a component of the nuclear factor (NF) $-\kappa B$ signaling pathway. We also found that SNX-2112 increased the expression of the differentiation transcription factors PU.1 and CCAAT-enhancer-binding protein- $\alpha$. Thus, SNX-2112 induced KG-1a cell differentiation, cell cycle arrest and apoptosis via modulation of Akt and NF- $\kappa \mathrm{B}$ signaling, suggesting that it is a promising therapeutic agent for the treatment of AML.
\end{abstract}

Correspondence to: Qiu-Ying Liu, Guangzhou Jinan Biomedicine Research and Development Center, Jinan University, 601 West HuangPu Road, Guangzhou, Guangdong 510632, P.R. China E-mail: qiuying_liu@126.com

Professor Qiu-Ling Xie, Guangdong Provincial Key Laboratory of Bioengineering Medicine, Jinan University, 601 West HuangPu Road, Guangzhou, Guangdong 510632, P.R. China

E-mail: txql@jnu.edu.cn

Abbreviations: AML, acute myeloid leukemia; GM, geldanamycin; 17-AAG, 17-(2-dimethylaminoethyl)amino-17-demethoxygeldanamycin; ATRA, all-trans-retinoic acid; CMP, common myeloid progenitor; GMP, granulocyte-monocyte progenitor; Bar, bardoxolone methyl

Key words: Hsp90 inhibitor, SNX-2112, KG-1a cells, differentiation, apoptosis

\section{Introduction}

Acute myeloid leukemia (AML) is a clinically and biologically heterogeneous clonal hematologic disorder that is common and lethal in adults (1). Even with improvements in diagnosis and supportive care, the 5-year survival rate for adults with AML is only $30 \%$. There have been no breakthroughs in AML treatment in the last 40 years, although in the past decade, an increasing number of potential drug targets have been identified (2).

Heat shock protein 90 (Hsp 90) is a chaperone protein required for the folding and stabilization of proteins involved in intracellular signaling such as Akt and the nuclear factor (NF) $\kappa \mathrm{B}$ signaling pathway component inhibitor of $\kappa \mathrm{B}$ kinase (IKK) $\alpha$, which regulate cell survival, proliferation and differentiation $(3,4)$. Hsp90 is overexpressed in many types of cancer relative to normal tissues and is therefore considered a potential anticancer drug target $(3,5)$. There are sixteen different Hsp90 inhibitors that have entered clinical testing including first generation Hsp90 inhibitors (geldanamycin and its derivatives) and second generation Hsp90 inhibitors (NVP-AUY922 and SNX-5422). However, there is no FDA approved Hsp90 inhibitor nor standardized assay to ascertain Hsp90 inhibition. The most clinically significant off-target toxicity with the geldanamycin derivatives was hepatotoxicity resulting from the presence of a benzoquinone moiety. In addition to hepatotoxicity, ocular and cardiac toxicities also limited further clinical development of these drugs (6-8). Therefore, development of an Hsp90 inhibitor with better pharmacological properties and a safety profile is important.

Most Hsp90 inhibitors exhibit great anti-acute myeloid leukemia effects. The second-generation Hsp90 inhibitor NVP-AUY922-AG was demonstrated to be cytotoxic in myeloid cell lines and primary AML cells (9), and other Hsp90 inhibitors were tested in phase I clinical trials and have been well tolerated in patients with advanced AML (10). SNX-2112 is a novel inhibitor that competitively binds to the N-terminal ATP-binding site of Hsp90 and has shown anticancer activity in vitro and in vivo $(3,11)$.

A hallmark of AML is that leukemic blast cells are arrested at an early stage of differentiation. It has therefore been suggested that therapies promoting differentiation may be 
effective for AML treatment, a concept known as differentiation therapy (12). All-trans-retinoic acid (ATRA) and arsenic trioxide used in combination with chemotherapy is the standard treatment for acute promyelocytic leukemia and is a potential paradigm for differentiation therapy in clinical oncology, but not for other subtypes of AML $(13,14)$. Studies have shown that isocitrate dehydrogenase (IDH), glycogen synthase kinase (GSK)-3, and dihydroorotate dehydrogenase inhibition induces AML cell differentiation (15-18), but there are no studies on whether the inhibition of Hsp90 can achieve this effect.

The transcription factor CCAAT/enhancer binding protein $\alpha(\mathrm{C} / \mathrm{EBP} \alpha)$ is a critical regulator of myeloid development that directs granulocyte and monocyte differentiation. Conditional $\mathrm{C} / \mathrm{EBP} \alpha$ deficiency in adult mice blocked the transition from common myeloid progenitor (CMP) to granulocyte-monocyte progenitor (GMP), resulting in decreased formation of both granulocytes and monocytes (19). In addition, the suppression of $\mathrm{C} / \mathrm{EBP} \alpha$ expression may block differentiation, and also stimulate proliferation of transformed cells (20). PU.1 is a member of the Ezb transformation-specific sequence family of transcription factors, which is expressed in granulocytes, monocytes and B-lymphoid cells (21), with its level increasing during differentiation. As such, PU.1 mutation, which has been identified in a subset of AML patients, has been linked to leukemogenesis (22). Both $\mathrm{C} / \mathrm{EBP} \alpha$ and PU.1 are required for differentiation of the granulocytic lineage.

Akt is a serine threonine kinase downstream of phosphoinositide 3-kinase (PI3K) that has many downstream targets associated with cell survival and cell cycle regulation, and also inhibits hematopoietic cell apoptosis (23). Nuclear factor (NF)- $\mathrm{B}$ regulates various biological processes linked to leukemogenesis, including cell proliferation, differentiation, autophagy and apoptosis, and is constitutively activated in AML cells $(24,25)$.

The present study investigated the potential of the Hsp90 inhibitor SNX-2112 to be used for treatment of AML using human acute leukemia KG-1a cells. We found that SNX-2112 induced cell cycle arrest at the G2/M phase and apoptosis while promoted differentiation and suppressed cell growth, effects that involve modulation of Akt and NF-kB signaling.

\section{Materials and methods}

Cell culture and reagents. Human AML KG-1a cells purchased from the Cell Bank of the Chinese Academy of Sciences (Shanghai, China) were cultured in Roswell Park Memorial Institute (RPMI)-1640 medium containing $15 \%$ fetal bovine serum (FBS) and $100 \mathrm{U} / \mathrm{ml}$ penicillin/streptomycin in a humidified incubator of $5 \% \mathrm{CO}_{2}$ at $37^{\circ} \mathrm{C}$. SNX-2112 was synthesized as previously described (26) with a purity $>98.0 \%$, and $10 \mathrm{mM}$ SNX-2112 stock solutions were prepared in dimethyl sulfoxide (DMSO) and stored at $4^{\circ} \mathrm{C}$. 17-AAG and bardoxolone methyl

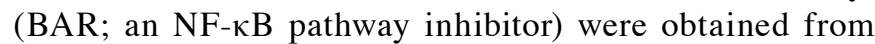
Selleck Chemicals (Houston, TX, USA). RPMI-1640 medium and FBS were purchased from Gibco (Grand Island, NY, USA). Antibodies against glyceraldehyde 3-phosphate dehydrogenase (GAPDH), caspase-3, Bcl-xl, Bcl-2, Akt, p-Akt (Thr308), IKK $\alpha$, IKK $\beta$, p65, p-p65, IкB, and PU.1 were purchased from Cell Signaling Technology (Beverly, MA, USA), and cluster of differentiation (CD)11b was purchased from BD Biosciences (Franklin Lakes, NJ, USA).
Cell proliferation assay. Cell proliferation was evaluated using Cell Counting Kit-8 (CCK-8). Briefly, 1.0x104 cells/well were seeded into 96-well plates and treated with SNX-2112 or 17-AAG for 24,48 or $72 \mathrm{~h}$. A $10-\mu \mathrm{l}$ volume of CCK-8 working solution was added to each well for $2 \mathrm{~h}$. The absorbance was assessed at $450 \mathrm{~nm}$ on a microplate reader (Bio-Rad, Hercules, CA, USA) and used to determine the drug concentration inhibiting growth by $50 \%\left(\mathrm{IC}_{50}\right)$.

Cell cycle analysis. KG-1a cells were seeded at $1.0 \times 10^{5}$ cells $/ \mathrm{ml}$ and treated with SNX-2112 for $48 \mathrm{~h}$. The cells were collected by centrifugation at $500 \mathrm{x}$ g for $5 \mathrm{~min} ; 70 \%$ ethanol was then added, followed by 2 washes with phosphate-buffered saline (PBS). Cells were resuspended in $1 \mathrm{ml}$ PBS containing $2.5 \mu \mathrm{g} / \mathrm{ml}$ ribonuclease and $50 \mu \mathrm{g} / \mathrm{ml}$ propidium iodide (PI) (Beyotime Institute of Biotechnology, Shanghai, China) and incubated in the dark for $30 \mathrm{~min}$ at room temperature before analysis by flow cytometry (BD FACSCalibur, Lake Franklin, NJ, USA; BD Biosciences).

Cell differentiation assay. Cells were seeded at $1.0 \times 10^{5} \mathrm{cell} / \mathrm{s} / \mathrm{ml}$ and incubated with SNX-2112 for $48 \mathrm{~h}$. The cells were collected by centrifugation at $500 \mathrm{x}$ g for $5 \mathrm{~min}$ and washed with PBS twice. Then, a 20- $\mu 1$ volume of CD11b was added for $20 \mathrm{~min}$ in the dark and analyzed by flow cytometry.

Cell apoptosis assay. Cells were seeded at $1.0 \times 10^{5}$ cells $/ \mathrm{ml}$ and incubated with SNX-2112/Bar for 48 h. Samples were prepared according to the instructions provided with the Annexin V-fluorescein isothiocyanate/PI stainingkit(Beyotime Institute of Biotechnology) and analyzed by flow cytometry.

Quantitative real-time ( $q R T)-P C R$. KG-1a cells were seeded at $1.0 \times 10^{5}$ cells $/ \mathrm{ml}$, and incubated with DMSO or SNX-2112 for $48 \mathrm{~h}$, and total RNA was immediately extracted using TRIzol reagent (Invitrogen, Carlsbad, CA, USA) according to the manufacturer's instructions. For analysis of PU.1 and C/EBP $\alpha$, $2 \mu \mathrm{g}$ of total RNA was used to synthesize first-strand DNA with reverse transcriptase (Promega, Madison, WI, USA). qRT-PCR was then carried out using Green PCR Master Mix (Shine Co., Shanghai, China), $1 \mu$ l of cDNA, gene-specific primers (Table I), and the Hot Start Fluo-PCR Mix in a $20-\mu 1$ reaction under the following cycling conditions: $95^{\circ} \mathrm{C}$ for $5 \mathrm{~min}$, followed by 35 cycles at $95^{\circ} \mathrm{C}$ for $10 \mathrm{sec}, 57^{\circ} \mathrm{C}$ for $15 \mathrm{sec}$, and $72^{\circ} \mathrm{C}$ for $20 \mathrm{sec}$. Each sample was prepared in triplicate and transcript levels were quantified using the $2^{-\Delta \Delta \mathrm{Ct}}$ method (27).

Immunofluorescence analysis. KG-1a cells cultured in 6-well plates were treated with DMSO or SNX-2112 $(0,0.25,0.5$ or $1 \mu \mathrm{M})$ for $48 \mathrm{~h}$. The cells were washed 3 times with ice-cold PBS and fixed with $4 \%$ paraformaldehyde. The cell membrane was permeabilized by adding $0.1 \%$ Triton X-100, and the cells were blocked with $5 \%$ bovine serum albumin (HyClone, Logan, UT, USA) and incubated for $2 \mathrm{~h}$ at room temperature with an antibody against NF-кB p65 (1:400) (Cell Signaling Technology), followed by incubation with a fluorophore-conjugated antirabbit antibody for $2 \mathrm{~h}$ at room temperature. The cells were then stained with PI (Beyotime Institute of Biotechnology) for $15 \mathrm{~min}$, and subsequently washed and examined with an epifluorescence microscope (Zeiss, Jena, Germany). 
Table I. Primers used for qRT-PCR.

\begin{tabular}{lcc}
\hline Gene name & & Sequence $\left(5^{\prime} \rightarrow 3^{\prime}\right)$ \\
\hline GAPDH & F & CGTCTTCACCACCATGGAGA \\
& R & CGGCCATCACGCCACAGTTT \\
PU.1 & F & GTGCCCTATGACACGGATCT \\
& R & GAAGCTCTCGAACTCGCTGT \\
C/EBP $\alpha$ & F & TGGACAAGAACAGCAACGAG \\
& R & TTGTCACTGGTCAGCTCCAG
\end{tabular}

F, forward; R, reverse; GAPDH, 3-phosphate dehydrogenase; $\mathrm{C} / \mathrm{EBP} \alpha, \mathrm{CCAAT} / \mathrm{enhancer}$ binding protein $\alpha$.

Western blotting. KG-1a cells were washed twice in ice-cold PBS, lysed in radioimmunoprecipitation buffer for $30 \mathrm{~min}$ on ice at $4^{\circ} \mathrm{C}$, and centrifuged at $12,000 \times \mathrm{g}$ for $15 \mathrm{~min}$. The protein content in the supernatant was determined with the bicinchoninic acid assay. Equivalent amounts (30-50 $\mu \mathrm{g})$ of protein were denatured in sodium dodecyl sulfate (SDS) sample buffer and resolved by 10-15\% SDS-polyacrylamide gel electrophoresis, and then transferred to an Immobilon polyvinylidene difluoride membrane, which was blocked in $5 \%$ skimmed milk in Tris-buffered saline containing $0.1 \%$ Tween-20 (TBST) at room temperature for $1 \mathrm{~h}$ and then probed with primary antibodies $(1: 1,000)$ overnight at $4{ }^{\circ} \mathrm{C}$. The membrane was washed 3 times for $10 \mathrm{~min}$ in TBST, and incubated with a secondary antibody $(1: 6,000-1: 8,000)$ in TBST with 5\% skimmed milk at room temperature for $1 \mathrm{~h}$. After washing, immunoreactivity was detected with an enhanced chemiluminescence kit (Pierce, Rockford, IL, USA). GAPDH served as a loading control.

Clone formation assay. Cells were treated with SNX-2112 or 17-AAG for 2 days, and then washed twice with PBS. The cells were seeded $\left(1 \times 10^{3}\right.$ cells/dish) in $1.5 \mathrm{ml}$ of $0.30-0.35 \%$ soft agar (Sigma-Aldrich, St. Louis, MO, USA) supplemented with $20 \% \mathrm{FBS}$ and cultured for 12 days at $37^{\circ} \mathrm{C}$ and $5 \% \mathrm{CO}_{2}$. After 12 days, the colonies were counted under a light microscope.

Statistical analysis. All data were confirmed by at least 3 independent experiments. Data are expressed as the mean \pm SD. Statistical significance was determined by one-way analysis of variance (ANOVA) and covariance calculated using GraphPad 6.0 (GraphPad Software, Inc., La Jolla, CA, USA). Differences between 2 groups were detected using two-tailed Student's t-test. $\mathrm{P}<0.05$ and $\mathrm{P}<0.01$ were considered to indicate a statistically significant result.

\section{Results}

SNX-2112 inhibits KG-la cells proliferation. The effects of SNX-2112 and 17-AAG on the viability of KG-1a cells were evaluated using CCK-8 assay. Both compounds showed dose- and time-dependent inhibition of KG-1a cells proliferation after 24,48 and $72 \mathrm{~h}$. The $\mathrm{IC}_{50}$ values of SNX-2112 were $1.02,0.29$ and $0.22 \mu \mathrm{M}$, respectively. These were lower than the $\mathrm{IC}_{50}$ values of 17-AAG, which were 209.6, 30.27 and $44.75 \mu \mathrm{M}$, respectively (Fig. 1A and B), indicating that SNX-2112 inhibits cell growth to a greater degree.

SNX-2112 induces cells cycle arrest at the G2/M phase. To determine whether cell growth inhibition by SNX-2112 is associated with cell cycle arrest, the cell cycle distribution was analyzed using flow cytometry. KG-1a cells treated with SNX-2112 were arrested in the G2/M phase after $48 \mathrm{~h}$ (Fig. 1C); the proportion of arrested cells was 22.5, 41.2 and $28.7 \%$ at concentrations of $0.25,0.5$ and $1 \mu \mathrm{M}$, respectively, as compared to $17 \%$ in the control group (Fig. 1D).

SNX-2112 induces differentiation and decreases colony formation. To determine whether KG-1a cells differentiation was affected by SNX-2112 treatment, we analyzed the expression of the differentiation marker CD11b by flow cytometry at 24 and $48 \mathrm{~h}$. CD11b expression was increased by treatment with SNX-2112 from 3.32 to $19.18 \%$ at $24 \mathrm{~h}$ (data not shown), and from 4.99 to $50.8 \%$ at $48 \mathrm{~h}$ (Fig. $2 \mathrm{~A}$ and B).

Since the aim of AML differentiation therapy is to suppress the growth of AML cells, we performed a colony formation assay to determine whether SNX-2112 induced irreversible growth arrest. KG-1a cells were exposed to the drug for 2 days, and after washing, an equal number of viable cells were plated on soft agar. A marked decrease in the number of colonies formed was observed upon treatment with SNX-2112 (Fig. 2C), indicating that SNX-2112 can cause KG-1a cells growth arrest, and that SNX-2112 was more potent than 17-AAG.

SNX-2112 induces KG-1a cells apoptosis. To determine whether SNX-2112 inhibits KG-1a cells growth by inducing apoptosis, the treated cells were labeled with Annexin V/PI and analyzed by flow cytometry. Annexin $\mathrm{V}^{+} / \mathrm{PI}^{-}$and Annexin $\mathrm{V}^{+} /$ $\mathrm{PI}^{+}$cells were designated as early apoptotic and necrotic cells, respectively. The number of apoptotic cells was increased from $3.93 \%$ in the control cells to $14.82,29.5$ and $35.2 \%$ by treatment with $0.25,0.5$ and $1 \mu \mathrm{M}$ SNX-2112, respectively, for $48 \mathrm{~h}$ (Fig. 3A and B). Moreover, the expression of the apoptosisrelated protein cleaved caspase- 3 was increased in the presence of SNX-2112, although that of B cell lymphoma (Bcl)-2 and Bcl-2-associated X protein were unaltered (Fig. 3C).

$S N X-2112$ inhibits Akt and $N F-\kappa B$ signaling. Hsp90 inhibition has been demonstrated to block PI3K and IKK signaling pathways (9). We therefore investigated whether SNX-2112 treatment affected the expression of Akt and IKK by western blotting. Previous studies revealed that Hsp90 was overexpressed in many types of cancer $(3,5)$. Our results revealed that Hsp90 was highly expressed in KG-1a cells, and Hsp90 client proteins IKK $\alpha$, IKK $\beta$ and Akt expression levels were downregulated upon treatment with SNX-2112 for 48 h (Fig. 4A). Consistent with previous studies (28), NF- $\kappa \mathrm{B}$ pathway inhibitor Bar, inhibited KG-1a cell proliferation and induced apoptosis (Fig. 4B-D). Bar is an IKK $\beta$-inhibitor which inhibited the expression of downstream protein p65 but did not directly interfere with the expression of IKK after treatment with Bar $(0.5 \mu \mathrm{M})$ for $48 \mathrm{~h}$ (Fig. 4E), as Bar could possibly block the upstream kinases that have been implicated in the activation of IKK (29). SNX-2112 treatment resulted in the upregulation of NF- $\kappa$ B 
A

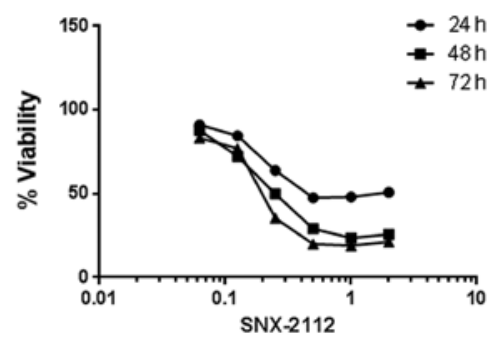

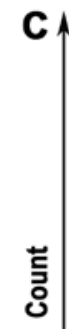
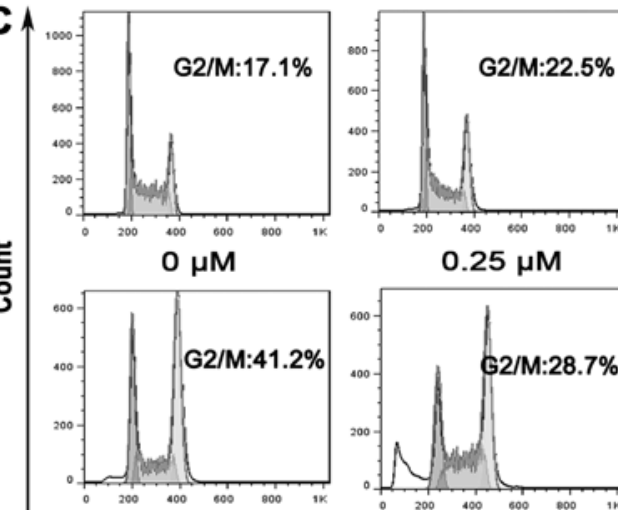

$0.5 \mu \mathrm{M}$

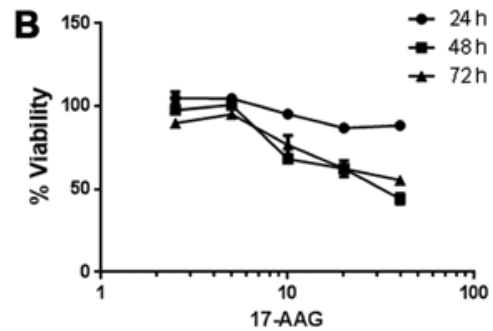

D

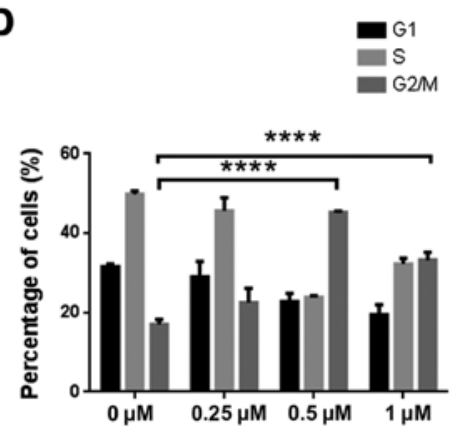

Figure 1. SNX-2112 inhibits proliferation and induces cell cycle arrest in KG-1a cells. (A and B) KG-1a cells were cultured in the presence of SNX-2112 or 17-AAG for 24,48 or $72 \mathrm{~h}$, and the cell proliferation was assessed using CCK-8 assay. (C and D) KG-1a cells were arrested at the G2/M phase with SNX-2112 treatment. Cells were treated with indicated concentrations of SNX-2112 and analyzed after 48 h by PI staining and flow cytometry. Data are presented as the mean \pm SEM ( $=3 /$ group); ${ }^{* * * *} \mathrm{P}<0.0001$ compared to the corresponding control.

A

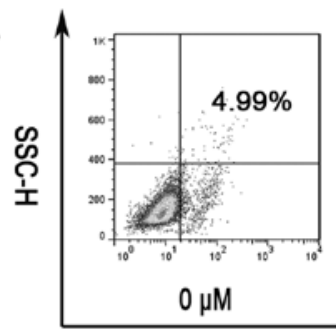

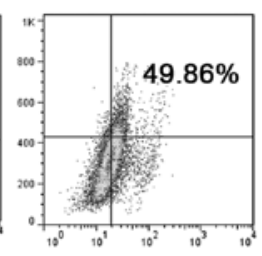

$0.5 \mu \mathrm{M}$

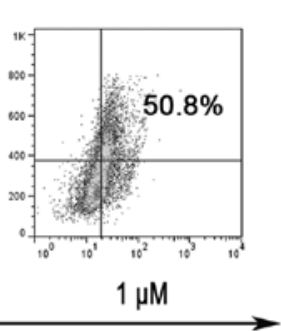

$0.25 \mu \mathrm{M}$

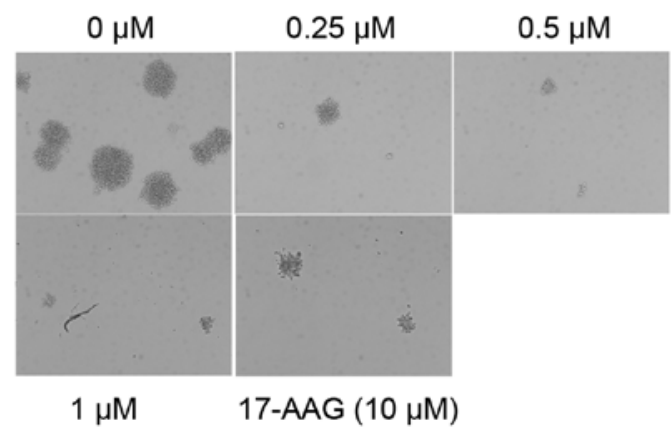

Figure 2. SNX-2112 induces differentiation and decreases colony formation in KG-1a cells (A and B) KG-1a cells were treated with indicated concentrations of SNX-2112 and analyzed after $48 \mathrm{~h}$ by flow cytometry. Representative bar graphs reveal the expression of the differentiation marker CD11b. Data are presented as the mean \pm SEM ( $n=3 /$ group); ${ }^{* * * * *} \mathrm{P}<0.0001$ compared to the corresponding control. (C) SNX-2112 suppresses clonal growth of KG-1a cells, as determined by the colony formation assay.

inhibitors (i.e., IкB) and downregulation of p65 and p-p65 after $48 \mathrm{~h}$ (Fig. 4F and G). Since C/EBP $\alpha$ and PU.1 play key roles in myeloid differentiation and NF- $\mathrm{kB}$ has been demonstrated to regulate PU.1 (30-32), we evaluated their expression after $48 \mathrm{~h}$ by qRT-PCR. The levels of both transcripts were increased by $>2$-fold in the presence of SNX-2112 (Fig. 5A and B). The 


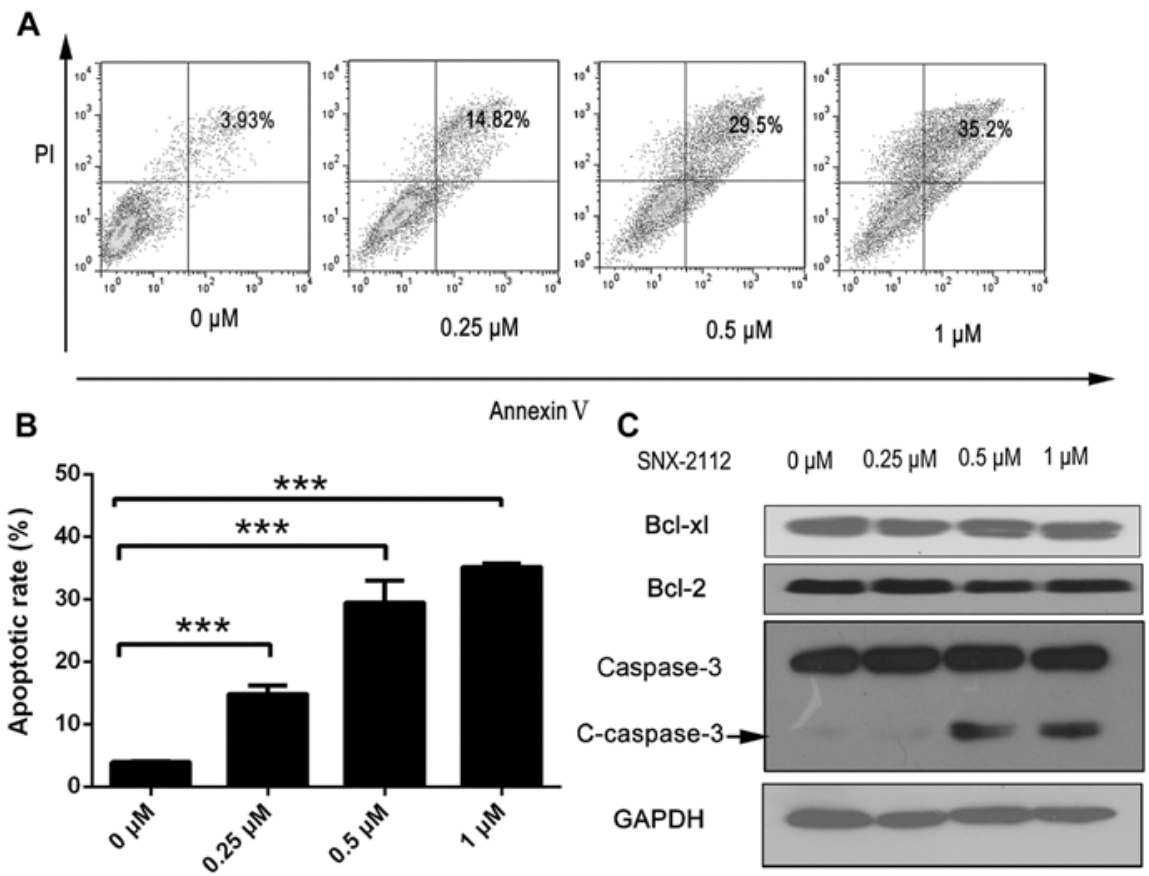

Figure 3. SNX-2112 induces KG-1a cell apoptosis. (A and B) KG-1a cells were treated with indicated concentrations of SNX-2112 and Annexin V/PI staining was detected after $48 \mathrm{~h}$ by flow cytometry. Data are presented as the mean \pm SEM ( $\mathrm{n}=3$ /group); ${ }^{* * *} \mathrm{P}<0.001$, the corresponding control. (C) KG-1a cells were treated with indicated concentrations of SNX-2112 for $48 \mathrm{~h}$ and Bcl-xl, Bcl-2, caspase-3 expressions were analyzed by western blotting.
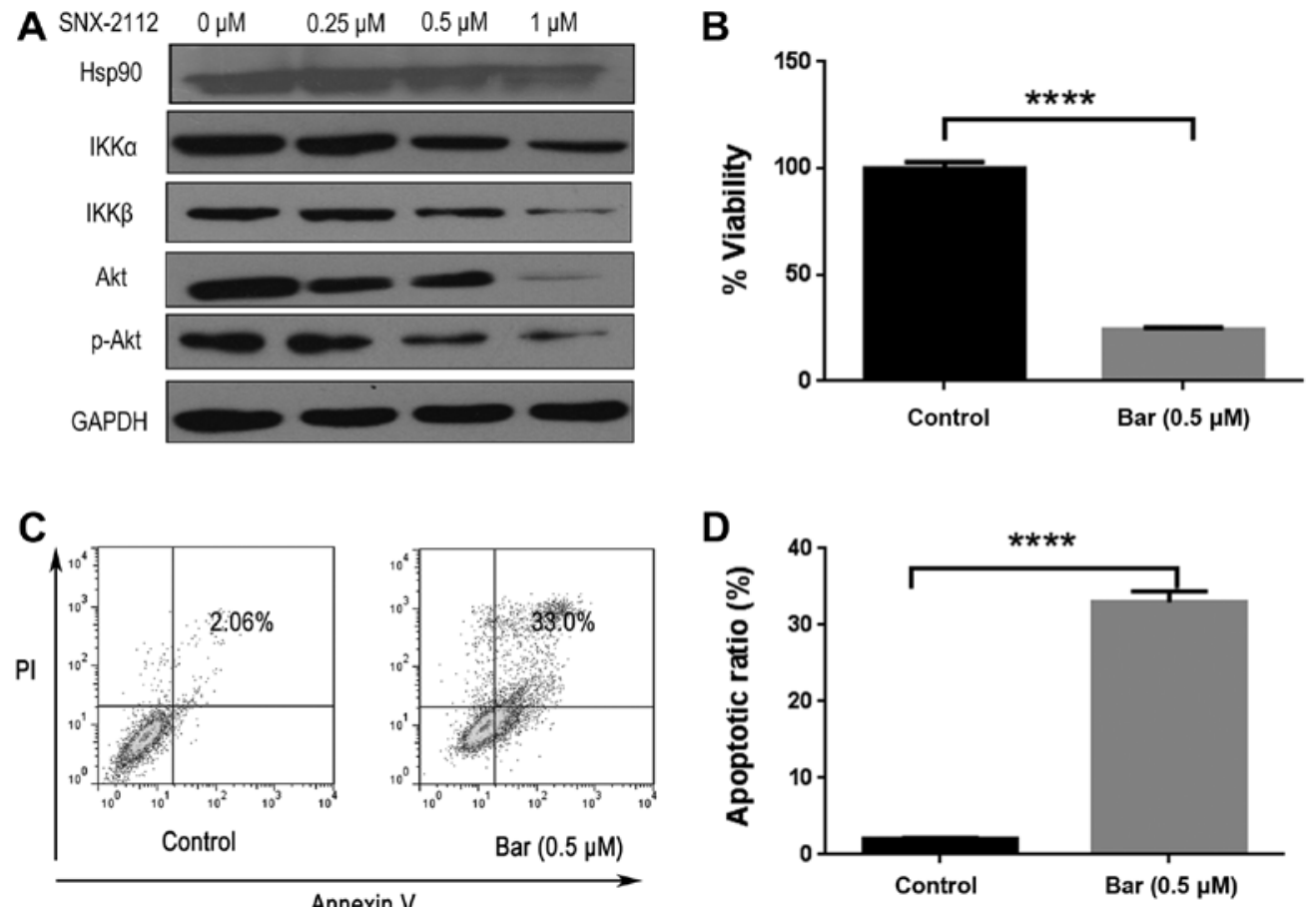

Figure 4. SNX-2112 inhibits Akt and NF-kB signaling. (A) KG-1a cells were treated with indicated concentrations of SNX-2112 for 48 h. Hsp90, IKK $\alpha$, IKK $\beta$, Akt and p-Akt were analyzed by western blotting relative to that of GADPH. (B) KG-1a cells were treated with an NF- $\mathrm{BB}$ pathway inhibitor (Bar, $0.5 \mu \mathrm{M})$ or left untreated (control) for $48 \mathrm{~h}$, and cell proliferation was assessed with CCK-8 assay. (C and D) KG-1a cells were treated with Bar (0.5 $\mu \mathrm{M})$ or a vehicle for $48 \mathrm{~h}$ and Annexin V/PI staining was detected after $48 \mathrm{~h}$ by flow cytometry. Data are presented as the mean $\pm \mathrm{SEM}\left(\mathrm{n}=3 /\right.$ group); ${ }^{* * * * * *} \mathrm{P}<0.0001 \mathrm{compared}$ to the corresponding control.

increase in PU.1 expression was confirmed by immunofluorescence analysis (Fig. 5C). These results indicate that inhibition of Hsp90 by SNX-2112 suppresses the expression of Akt and IKK and induces that of C/EBP $\alpha$ and PU.1 via inhibition of NF- $\mathrm{KB}$ signaling in KG-1a cells.

\section{Discussion}

Hsp90 is overexpressed in most cancers; pharmacological inhibition of this protein can induce apoptosis in hematologic and other types of tumors (9). In the present study, we 

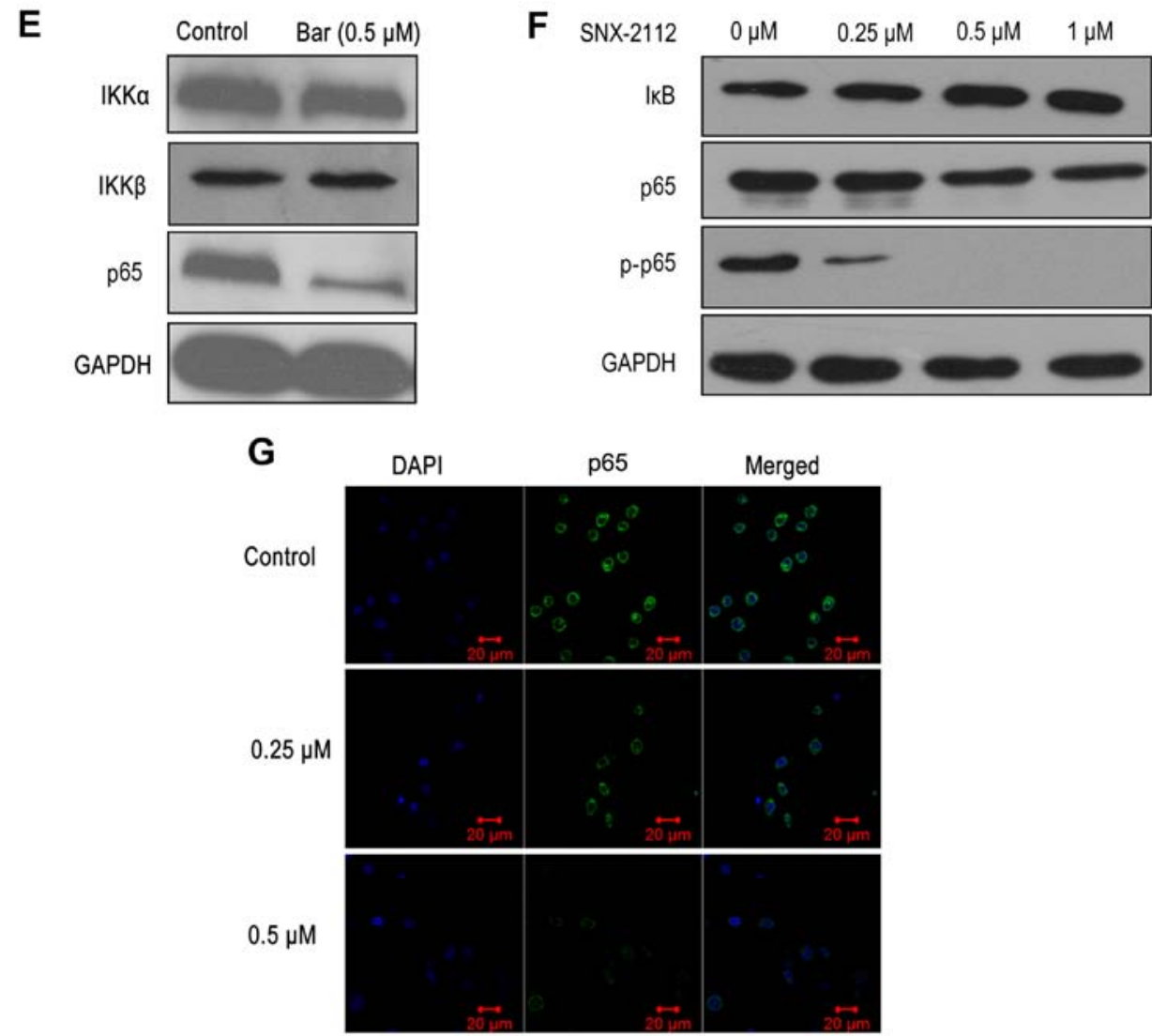

Figure 4. Continued. SNX-2112 inhibits Akt and NF-кB signaling. (E) KG-1a cells were treated with Bar $(0.5 \mu \mathrm{M})$ or left untreated (control) for $48 \mathrm{~h}$. IKK $\alpha$, IKK $\beta$ and p65 levels were analyzed by western blotting relative to that of GADPH. (F) KG-1a cells were treated with indicated concentrations of SNX-2112 for $48 \mathrm{~h}$. IкB, p65 and p-p65 levels were analyzed by western blotting relative to that of GADPH. (G) KG-1a cells were treated with indicated concentrations of SNX-2112 for $48 \mathrm{~h}$ and p65 expression was detected by immunofluorescence labeling. Nuclear cytoplasmic expression of NF- $\mathrm{kB}$ p 65 was decreased by SNX-2112 treatment.

A

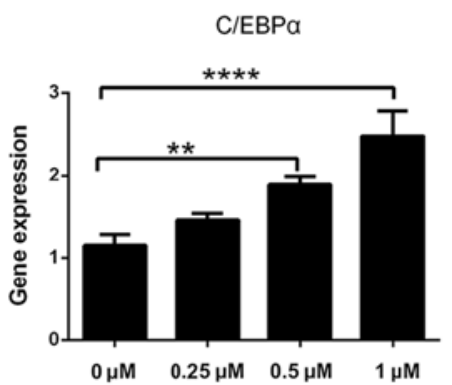

B

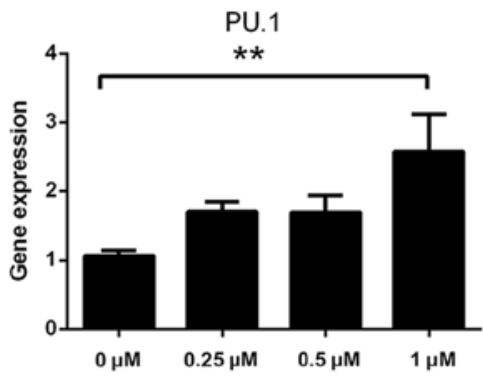

C

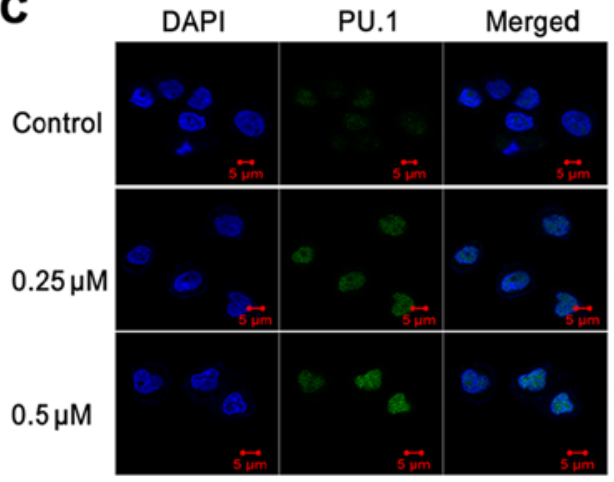

Figure 5. SNX-2112 upregulates C/EBP $\alpha$ and PU.1. (A and B) SNX-2112 upregulates C/EBP $\alpha$ and PU.1. Cells were treated with indicated concentrations of SNX-2112 for $48 \mathrm{~h}$, and C/EBP $\alpha$ and PU.1 expression was evaluated by qRT-PCR. Data are presented as the mean \pm SEM $(\mathrm{n}=3 / \mathrm{group}){ }^{* * *} \mathrm{P}<0.01$ and ${ }^{* * * * *} \mathrm{P}<0.0001$ compared to the corresponding control. (C) SNX-2112 treatment increases PU.1 expression. Cells were treated with indicated concentrations of SNX-2112 for $48 \mathrm{~h}$, and PU.1 was detected by immunofluorescence labeling. PU.1 immunoreactivity was significantly decreased in the nucleus.

demonstrated that the Hsp90 inhibitor SNX-2112 suppressed the proliferation of KG-1a cells and induced their arrest in the $\mathrm{G} 2 / \mathrm{M}$ phase and their differentiation and apoptosis in a time- and dose-dependent manner. Previous studies have revealed that SNX-2112 affects the activity and expression of Hsp90 client proteins (11), and our results revealed that SNX-2112 treatment resulted in the downregulation of the Hsp90-associated proteins Akt and IKK $\alpha$ as well as cleavage of caspase-3. We previously demonstrated that SNX-2112 suppressed K562 cell proliferation (33). Other studies have reported that it also inhibits the growth of multiple myeloma and other hematologic tumors (34). In the present study SNX-2112 had more potent effects than the classical Hsp90 inhibitor 17-AAG in KG-1a human acute leukemia cells.

AML is characterized by uncontrolled proliferation of myeloid progenitors that have decreased capacity for 
differentiation into mature granulocytes or macrophages (35). Differentiation therapy is a promising approach for the treatment of AML. Small-molecule inhibitors of mutant IDH2 (15) or IDH1 (16) can induce tumor cell differentiation in a subset $(15 \%)$ of AML patients with $I D H 1 / 2$ mutations; GSK-3 inhibition sensitizes AML cells to differentiation induced by an ATRA analog (17), with inhibition of dihydroorotate dehydrogenase having a similar effect (18). It has been reported that co-treatment with tubacin and 17-AAG decreased the viability of primary AML cells (36), whereas 17-AAG suppressed the growth of lymphoma stem cells (37). However, few studies have investigated the effect of HSP90 inhibition on AML. In the present study, we found that the Hsp90 inhibitor SNX-2112 promoted the differentiation of KG-1a cells.

Aberrant expression of $\mathrm{C} / \mathrm{EBP} \alpha$ and PU.1 contributes to the development of AML. PU.1 is a critical transcription factor during early granulopoiesis; PU.1 deficiency impairs hematopoietic development and can lead to leukemia (38). But PU.1 knockdown inhibited the proliferation of human AML U937 cells (39). In contrast, $\mathrm{C} / \mathrm{EBP} \alpha$ expression is required for the differentiation of myeloid lineage cells, and $\mathrm{C} / \mathrm{EBP} \alpha$ overexpression in primary human $\mathrm{CD} 4^{+}$cells led to granulocytic differentiation (40). In the present study, we found that $\mathrm{C} / \mathrm{EBP} \alpha$ and PU.1 were upregulated by SNX-2112 treatment, indicating that this drug induces AML cell differentiation by increasing $\mathrm{C} / \mathrm{EBP} \alpha$ and PU.1 levels.

The Hsp90 inhibitor NVP-AUY922-AG has been reported to induce apoptosis of AML cells by inhibiting the PI3K and IKK signaling pathways (9). Our findings indicate that Bar blocks KG-1a cell proliferation and induces apoptosis. Since p65 is constitutively active in AML (25), we speculated that IKK signaling is activated in KG-1a cells. SNX-2112 treatment decreased IKK expression as well as p65 expression, phosphorylation, and nuclear translocation. It has been previously shown that p65 regulates PU.1 expression to induce myeloid differentiation (32). Additionally, PU.1 expression is suppressed as a result of $\mathrm{C} / \mathrm{EBP} \alpha$ inhibition (20). We propose that SNX-2112 exerts its effects on KG-1a cells by inhibiting $\mathrm{NF}-\kappa \mathrm{B}$ signaling and modulating the expression of PU.1 and $\mathrm{C} / \mathrm{EBP} \alpha$, although additional studies are warranted to clarify the detailed molecular mechanisms. Nonetheless, our results suggest that SNX-2112 is a promising therapeutic agent for the treatment of AML.

\section{Acknowledgements}

The present study was supported by the Postdoctoral Science Foundation of China (2015M582472), the Natural Science Foundation of Guangdong Province (2014A030310434), and the National Natural Science Foundation of China (81500227)

\section{References}

1. De Kouchkovsky I and Abdul-Hay M: 'Acute myeloid leukemia: A comprehensive review and 2016 update'. Blood Cancer J 6: e441, 2016.

2. Kadia, TM, Ravandi F, Cortes J and Kantarjian H: New drugs in acute myeloid leukemia. Ann Oncol 27: 770-778, 2016.

3. Brandt GE and Blagg BS: Alternate strategies of Hsp90 modulation for the treatment of cancer and other diseases. Curr Top Med Chem 9: 1447-1461, 2009.
4. Patki JM and Pawar SS: HSP90: Chaperone-me-not. Pathol Oncol Res 19: 631-640, 2013.

5. Siegelin MD: Inhibition of the mitochondrial Hsp90 chaperone network: A novel, efficient treatment strategy for cancer? Cancer Lett 333: 133-146, 2013.

6. Jhaveri K and Modi S: Ganetespib: Research and clinical development. Onco Targets Ther 8: 1849-1858, 2015.

7. Jhaveri K, Taldone T, Modi S and Chiosis G: Advances in the clinical development of heat shock protein 90 (Hsp90) inhibitors in cancers. Biochim Biophys Acta 1823: 742-755, 2012.

8. Gartner EM, Silverman P, Simon M, Flaherty L, Abrams J, Ivy P and Lorusso PM: A phase II study of 17-allylamino-17-demethoxygeldanamycin in metastatic or locally advanced, unresectable breast cancer. Breast Cancer Res Treat 131: 933-937, 2012.

9. Walsby EJ, Lazenby M, Pepper CJ, Knapper S and Burnett AK: The HSP90 inhibitor NVP-AUY922-AG inhibits the PI3K and IKK signalling pathways and synergizes with cytarabine in acute myeloid leukaemia cells. Br J Haematol 161: 57-67, 2013.

10. Lancet JE, Gojo I, Burton M, Quinn M, Tighe SM, Kersey K, Zhong Z, Albitar MX, Bhalla K, Hannah AL, et al: Phase I study of the heat shock protein 90 inhibitor alvespimycin (KOS-1022, 17-DMAG) administered intravenously twice weekly to patients with acute myeloid leukemia. Leukemia 24: 699-705, 2010.

11. Chandarlapaty S, Sawai A, Ye Q, Scott A, Silinski M, Huang K, Fadden P, Partdrige J, Hall S, Steed P, et al: SNX2112, a synthetic heat shock protein 90 inhibitor, has potent antitumor activity against HER kinase-dependent cancers. Clin Cancer Res 14: 240-248, 2008.

12. Eitan Fibach, Makoto Hayashi and Sachs, L: Control of normal differentiation of myeloid leukemic cells. Proc Natl Acad Sci USA 70: 343-346, 1973.

13. Haanen $\mathrm{C}$ and Vermes I: Arsenic trioxide, a new drug for the treatment of acute promyelocytic leukemia resistant to tretinoine. Ned Tijdschr Geneeskd 143: 1738-1741, 1999 (In Dutch).

14. Huang ME, Ye YC, Chen SR, Chai JR, Lu JX, Zhoa L, Gu LJ and Wang ZY: Use of all-trans retinoic acid in the treatment of acute promyelocytic leukemia. Blood 72: 567-572, 1988.

15. Wang F, Travins J, DeLaBarre B, Penard-Lacronique V, Schalm S, Hansen E, Straley K, Kernytsky A, Liu W, Gliser C, et al: Targeted inhibition of mutant IDH2 in leukemia cells induces cellular differentiation. Science 340: 622-626, 2013.

16. Okoye-Okafor UC, Bartholdy B, Cartier J, Gao EN, Pietrak B, Rendina AR, Rominger C, Quinn C, Smallwood A, Wiggall KJ, et al: New IDH1 mutant inhibitors for treatment of acute myeloid leukemia. Nat Chem Biol 11: 878-886, 2015.

17. Gupta K, Stefan T, Ignatz-Hoover J, Moreton S, Parizher G, Saunthararajah Y and Wald DN: GSK-3 inhibition sensitizes acute myeloid leukemia cells to $1,25 \mathrm{D}$-mediated differentiation. Cancer Res 76: 2743-2753, 2016.

18. Sykes DB, Kfoury YS, Mercier FE, Wawer MJ, Law JM, Haynes MK, Lewis TA, Schajnovitz A, Jain E, Lee D, et al: Inhibition of dihydroorotate dehydrogenase overcomes differentiation blockade in acute myeloid leukemia. Cell 167: 171-186. e15, 2016.

19. Zhang P, Iwasaki-Arai J, Iwasaki H, Fenyus ML, Dayaram T, Owens BM, Shigematsu H, Levantini E, Huettner CS, Lekstrom-Himes JA, et al: Enhancement of hematopoietic stem cell repopulating capacity and self-renewal in the absence of the transcription factor C/EBP alpha. Immunity 21: 853-863, 2004.

20. Zheng R, Friedman AD, Levis M, Li L, Weir EG and Small D: Internal tandem duplication mutation of FLT3 blocks myeloid differentiation through suppression of $\mathrm{C} / \mathrm{EBPalph}$ expression. Blood 103: 1883-1890, 2004.

21. Chen HM, Zhang P, Voso MT, Hohaus S, Gonzalez DA, Glass CK, Zhang DE and Tenen DG: Neutrophils and monocytes express high levels of PU.1 (Spi-1) but not Spi-B. Blood 85: 2918-2928, 1995.

22. Renneville A, Roumier C, Biggio V, Nibourel O, Boissel N, Fenaux P and Preudhomme C: Cooperating gene mutations in acute myeloid leukemia: A review of the literature. Leukemia 22: 915-931, 2008.

23. Nicholson KM and Anderson NG: The protein kinase B/Akt signalling pathway in human malignancy. Cell Signal 14: 381-395, 2002.

24. Bueso-Ramos CE, Rocha FC, Shishodia S, Medeiros LJ, Kantarjian HM, Vadhan-Raj S, Estrov Z, Smith TL, Nguyen MH and Aggarwal BB: Expression of constitutively active nuclear $-\kappa B$ RelA transcription factor in blasts of acute myeloid leukemia. Hum Pathol 35: 246-253, 2004. 
25. Guzman ML, Neering SJ, Upchurch D, Grimes B, Howard DS, Rizzieri DA, Luger SM and Jordan CT: Nuclear factor- $\kappa B$ is constitutively activated in primitive human acute myelogenous leukemia cells. Blood 98: 2301-2307, 2001.

26. Barta TE, Veal JM, Rice JW, Partridge JM, Fadden RP, Ma W, Jenks M, Geng L, Hanson GJ, Huang KH, et al: Discovery of benzamide tetrahydro- $4 H$-carbazol-4-ones as novel small molecule inhibitors of Hsp90. Bioorg Med Chem Lett 18: 3517-3521, 2008.

27. Chen Y, Liu ZH, Xia J, Li XP, Li KQ, Xiong W, Li J and Chen DL: $20(S)$-ginsenoside $\mathrm{Rh} 2$ inhibits the proliferation and induces the apoptosis of KG-1a cells through the Wnt/ $\beta$-catenin signaling pathway. Oncol Rep 36: 137-146, 2016.

28. Konopleva M, Tsao T, Ruvolo P, Stiouf I, Estrov Z, Leysath CE, Zhao S, Harris D, Chang S, Jackson CE, et al: Novel triterpenoid $\mathrm{CDDO}-\mathrm{Me}$ is a potent inducer of apoptosis and differentiation in acute myelogenous leukemia. Blood 99: 326-335, 2002.

29. Shishodia S, Sethi G, Konopleva M, Andreeff $M$ and Aggarwal BB: A synthetic triterpenoid, CDDO-Me, inhibits IkappaBalpha kinase and enhances apoptosis induced by TNF and chemotherapeutic agents through down-regulation of expression of nuclear factor kappaB-regulated gene products in human leukemic cells. Clin Cancer Res 15: 1828-1838, 2006.

30. Scott LM, Civin CI, Rorth P and Friedman AD: A novel temporal expression pattern of three C/EBP family members in differentiating myelomonocytic cells. Blood 80: 1725-1735, 1992.

31. Fisher RC and Scott EW: Role of PU.1 in hematopoiesis. Stem Cells 16: 25-37, 1998 .

32. Gerloff D, Grundler R, Wurm AA, Bräuer-Hartmann D, Katzerke C, Hartmann JU, Madan V, Müller-Tidow C, Duyster J, Tenen DG, et al: NF- $\mathrm{B} / \mathrm{STAT} 5 / \mathrm{miR}-155$ network targets PU.1 in FLT3-ITD-driven acute myeloid leukemia. Leukemia 29 535-547, 2015.
33. Jin L, Xiao CL, Lu CH, Xia M, Xing GW, Xiong S, Liu QY, Liu H, Li YC, Ge F, et al: Transcriptomic and proteomic approach to studying SNX-2112-induced K562 cells apoptosis and anti-leukemia activity in K562-NOD/SCID mice. FEBS Lett 583: 1859-1866, 2009.

34. Okawa Y, Hideshima T, Steed P, Vallet S, Hall S, Huang K, Rice J, Barabasz A, Foley B, Ikeda H, et al: SNX-2112, a selective Hsp90 inhibitor, potently inhibits tumor cell growth, angiogenesis, and osteoclastogenesis in multiple myeloma and other hematologic tumors by abrogating signaling via Akt and ERK. Blood 113: 846-855, 2009

35. Roe JS and Vakoc CR: C/EBP $\alpha$ : Critical at the origin of leukemic transformation. J Exp Med 211: 1-4, 2014.

36. Rao R, Fiskus W, Yang Y,Lee P,Joshi R, FernandezP,Mandawat A, Atadja P, Bradner JE and Bhalla K: HDAC6 inhibition enhances 17-AAG - mediated abrogation of hsp90 chaperone function in human leukemia cells. Blood 112: 1886-1893, 2008.

37. Newman B, Liu Y, Lee HF, Sun D and Wang Y: HSP90 inhibitor 17-AAG selectively eradicates lymphoma stem cells. Cancer Res 72: 4551-4561, 2012.

38. Iwasaki H, Somoza C, Shigematsu H, Duprez EA, Iwasaki-Arai J, Mizuno S, Arinobu Y, Geary K, Zhang P, Dayaram T, et al: Distinctive and indispensable roles of PU.1 in maintenance of hematopoietic stem cells and their differentiation. Blood 106: 1590-1600, 2005.

39. Zhou J, Zhang X, Wang Y and Guan Y: PU.1 affects proliferation of the human acute myeloid leukemia U937 cell line by directly regulating MEIS1. Oncol Lett 10: 1912-1918, 2015.

40. Cammenga J, Mulloy JC, Berguido FJ, MacGrogan D, Viale A and Nimer SD: Induction of C/EBPalpha activity alters gene expression and differentiation of human $\mathrm{CD}^{2} 4^{+}$cells. Blood 101: 2206-2214, 2003 